\title{
PENGARUH RISIKO BISNIS, UKURAN PERUSAHAAN DAN PERTUMBUHAN PENJUALAN TERHADAP STRUKTUR MODAL PADA PERUSAHAAN PROPERTI DAN REAL ESTATE YANG TERDAFTAR DI BURSA EFEK INDONESIA
}

\author{
I Gusti Agung Ayu Meilyani ${ }^{1}$, Ni Made Suci ${ }^{2}$, Wayan Cipta ${ }^{3}$ \\ 1,2,3 Jurusan Manajemen, Universitas Pendidikan Ganesha, Singaraja \\ e-mail: meliyaniayu30@gmail.com, made.suci@undiksha.ac.id, wayan.cipta@undiksha.ac.id
}

\begin{abstract}
Abstrak
Penelitian ini bertujuan untuk mengetahui pengaruh risiko bisnis, ukuran perusahaan dan pertumbuhan penjualan terhadap struktur modalsecara simultan dan parsial pada perusahaan properti dan real estate.Subjek penelitian ini adalah perusahaan properti dan real estate dan objek penelitian adalah risiko bisnis, ukuran perusahaan, pertumbuhan penjualan dan struktur modal.Data dikumpulkan dengan pencatatan dokumen, dan dianalisis dengan analisis regresi linier berganda. Hasil penelitian menunjukkan bahwa (1) ada pengaruh signifikan secara simultan dari risiko bisnis, ukuran perusahaan dan pertumbuhan penjualan terhadap struktur modalsebesar $28,6 \%$, (2) ada pengaruh positif namun tidak signifikan secara parsial dari risiko bisnis terhadap struktur modalsebesar $0,9 \%$, (3) ada pengaruh negatif dan signifikan secara parsial dari ukuran perusahaan terhadap struktur modalsebesar $50,7 \%$, (4) ada pengaruh negatif namun tidak signifikan secara parsial dari pertumbuhan penjualanterhadap struktur modal sebesar $18,9 \%$.
\end{abstract}

Kata Kunci: pertumbuhan penjualan, risiko bisnis, struktur modal,ukuran perusahaan

\begin{abstract}
This study aims to determine the effect of business risk, company size and sales growth on capital structure simultaneously and partially on property and real estate companies. The subjects of this research are property and real estate companies and the object of research is business risk, company size, sales growth and capital structure. Data is collected by document recording, and analyzed by multiple linear regression analysis. The results showed that (1) there was a simultaneous significant effect of business risk, company size and sales growth on capital structure of $53.5 \%$, (2) there was a positive but not partially significant effect of business risk on capital structure of $0,9 \%$, (3) there is a negative and partially significant effect of company size on the capital structure of $50.7 \%$, (4) there is a negative but not partially significant effect of sales growth on the capital structure of $18.9 \%$.
\end{abstract}

Keywords: bussines risk, capital structure, company size, sales growth 


\section{Pendahuluan}

Akhir-akhir ini kondisi ekonomi dan persaingan usaha antar perusahaan sangatlah ketat sehingga banyak manajer keuangan mulai berfikir strategis dan memberi perhatian pada masalah-masalah pendanaan dibandingkan dengan masalah yang lainnya untuk dapat menjamin kelangsungan hidup perusahaan tersebut. Dalam menjalankan perusahaan, modal merupakan salah satu bagian penting dari suatu perusahaan. Kebutuhan akan modal sangat penting dalam membangun dan menjamin kelangsungan perusahaan. Struktur modal juga dapat di definisikan sebagai perimbangan atau perbandingan antara utang jangka panjang dengan modal sendiri (Riyanto 2001: 28). Oleh karena itu, manajer harus mampu menghimpun dana baik yang bersumber dari dalam perusahaan maupun luar perusahaan secara efisien, dalam arti keputusan pendanaan tersebut merupakan keputusan pendanaan yang mampu meminimalkan biaya modal yang harus ditanggung perusahaan.

Struktur modal dipengaruhi oleh faktor dari luar perusahaan maupun di dalam perusahaan. Faktor eksternal perusahaan meliputi kondisi pasar modal, tingkat bunga, dan stabilitas politik, sedangkan faktor internal seperti profitabilitas perusahaan, ukuran perusahaan, dan stabilitas dividen (Winahyuningsih dkk., 2011). Brigham dan Houston (2011: 188), menjelaskan faktor-faktor struktur modal yaitu: stabilitas penjualan, struktur aktiva, leverage operasi, risiko bisnis, tingkat pertumbuhan, profitabilitas, pajak, pengendalian, sikap manajemen, ukuran perusahaan dan fleksibilitas keuangan. Berdasarkan beberapa faktor yang memengaruhi struktur modal, penelitian ini menggunakan tiga faktor pada Sektor Real Estate dan Properti yang terdaftar di BEI periode 2017 - 2018. Ketiga faktor tersebut, yaitu risiko bisnis, ukuran perusahaan dan pertumbuhan penjualan perusahaan. Pemilihan ketiga faktor tersebut didasarkan karena ketiga faktor tersebut merupakan faktor internal perusahaan, dimana kondisi internal perusahaan sangat menentukan komposisi struktur modal perusahaan. Berdasarkan studi pendahuluan terhadap perusahaan properti dan real estate yang terdaftar di $\mathrm{BEI}$, diperoleh data mengenai struktur modal, risiko bisnis, ukuran perusahaan dan pertumbuhan penjualan dari tahun 2017 - 2018 menunjukkan adanya kenaikan struktur modal namun risiko bisnis mengalami penurunan seperti yang dialami pada 3 perusahaan yaitu perusahaan Megapolitan Development Tbk mengalami penurunan risiko bisnis sebesar 0,05 dimana pada tahun 2017 risiko bisnis perusahaan tersebut berada pada angka 0,06 kemudian pada tahun 2018 menurun menjadi 0,01 sedangkan struktur modal meningkat sebesar 0,24. Kemudian pada perusahaan Jaya Real Properti Tbk mengalami penurunan struktur modal sebesar 0,1 namun ukuran perusahaan tersebut justru meningkat dari 16,06 menjadi 16,17 . Tidak hanya itu, tingkat pertumbuhan penjualan pada perusahaan Megapolitan Development Tbk mengalami penurunan dari awalnya 0,20 menurun menjadi 0,43 namun struktur modal pada perusahaan tersebut meningkat dari 1,37 menjadi 1,61.

Risiko bisnis merupakan salah satu faktor yang mempengaruhi keputusan manajer dalam menentukan struktur modal perusahaan. Risiko bisnis adalah ketidakpastian yang dihadapi perusahaan dalam menjalankan kegiatan bisnisnya. Dalam suatu perusahaan, risiko bisnis meningkat jika menggunakan utang yang tinggi. Studi Joni dan Lina (2010) menemukan bahwa risiko bisnis tidak berpengaruh signifikan terhadap struktur modal. Namun hal tersebut bertentangan dengan penelitian Indrajaya dkk., (2011) yang menyatakan bahwa risiko bisnis berpengaruh positif tidak signifikan terhadap struktur modal, selain itu Prabansari dan Kusuma (2005) menunjukkan bahwa risiko bisnis berpengaruh negatif dan signifikan terhadap struktur modal perusahaan.

Ukuran perusahaan mencerminkan seberapa mampu perusahaan dalam melakukan penjualan atas produk atau jasanya dan jumlah tenaga kerja yang dimiliki yang dapat dikatakan sebagai total aset dari perusahaan. Perusahaan yang memiliki ukuran besar akan mempermudah memperoleh tambahan modal di pasar modal dibandingkan dengan perusahaan yang berukuran kecil (Kartika, 2009). Al-Shubiri (2010) menyatakan hal yang sama bahwa, besarnya komponen hutang akan berhubungan positif dengan ukuran perusahaan. Perbedaan hasil penelitian dikemukakan oleh Liem (2013), bahwa ukuran perusahaan (firm size) tidak berpengaruh signifikan dan memiliki hubungan yang negatif terhadap struktur modal. 
Perusahaan yang memiliki tingkat pertumbuhan yang besar akan membutuhkan penambahan aset guna mendukung pertumbuhan penjualan sehingga perusahaan memiliki pertumbuhan yang besar menggunakan hutang yang lebih banyak (Heriyani, 2011). Sayilgan et al., (2006), menyatakan perusahaan yang memiliki tingkat penjualan yang tinggi akan lebih menguntungkan jika memakai hutang, namun penelitian yang dilakukan Andre (2014) menunjukkan sebaliknya bahwa pertumbuhan perusahaan berpengaruh negatif terhadap struktur modal.

Sektor Properti dan Real Estate merupakan bisnis yang bergerak dalam bidang pengembangan properti dan bangunan, seperti apartemen, perumahan, rukan dan office space, ruko dan mall, tanah kavling, dan town house. Semakin banyaknya pertambahan populasi yang disertai tingginya taraf hidup dan kemudahan dalam memperoleh tempat tinggal nyaman membuat kebutuhan masyarakat akan perusahaan ini semakin tinggi sehingga bisnis ini sangat menarik bagi para investor dalam melakukan investasi. Melihat adanya perkembangan industri properti dan real estate yang sangat pesat akhir-akhir ini, dan juga adanya kesenjangan antara data dengan teori yang ada disertai hasil penelitian yang tidak konsisten, maka peneliti ingin mengetahui faktor-faktor yang memengaruhi keputusan pendanaan perusahaan Properti dan Real Estate dari segi risiko bisnis, ukuran perusahaan dan pertumbuhan penjualan pada peusahaan subsektor properti dan real estate di Bursa Efek Indonesia tahun 2017 - 2018.

Adapun tujuan penelitian ini adalah untuk menguji dan menganalisis pengaruh: (1) Risiko bisnis, ukuran perusahaan dan pertumbuhan penjualan terhadap srtuktur modal pada perusahaan properti dan real estate yang terdaftar pada Bursa Efek Indonesia (2) Risiko bisnis terhadap struktur modalpada perusahaan properti dan real estate yang terdaftar pada Bursa Efek Indonesia (3) Ukuran perusahaan terhadap struktur modalpada perusahaan properti dan real estate yang terdaftar pada Bursa Efek Indonesia (4) Pertumbuhan penjualan terhadap struktur modalpada perusahaan properti dan real estate yang terdaftar pada Bursa Efek Indonesia.

Secara umum terdapat dua manfaat yang diharapkan dari adanya penelitian ini yaitu manfaat teoritis dan praktis. Secara rinci kedua manfaat hasil penelitian dapat diuraikan sebagai berikut: (1) Manfaat secara teoretis dapat dijadikan sebagai bahan masukan dan sumbangan pemikiran yang dapat menambah perbendaharaan dan pengetahuan di bidang manajemen keuangan (2) Manfaat secara praktis diharapakan penelitian ini dapat menjadi bahan pertimbangan dan memberi informasi kepada pengambil kebijakan perusahaan bersangkutan dalam keputusan pendanaan untuk perusahaannya dengan fokus pada risiko bisnis, ukuran perusahaan dan pertumbuhan penjualan.

Risiko bisnis, ukuran perusahaan dan pertumbuhan penjualan dapat memengaruhi struktur modal suatu perusahaan. Risiko bisnis, ukuran perusahaan dan pertumbuhan penjualanmerupakan hal yang penting yang harus diperhatikan dalam pencapaian struktur modal perusahaan. Risiko bisnis, ukuran perusahaan dan pertumbuhan penjualan berbanding lurus dengan struktur modal. Hal ini dapat dibuktikan dengan penelitian penelitian yang dilakukan oleh Wimelda dan Marlinah (2013), Joni dan Lina (2010), serta Theresia (2007) menemukan hasil bahwa risiko bisnis mempunyai pengaruh positif pada struktur modal. Sedangkan hasil penelitian yang dilakukan oleh Thian (2012), ukuran perusahaan berpengaruh positif pada struktur modal. Kemudian, untuk pertumbuhan penjualan penelitian empiris yang telah dilakukan antara lain oleh Krishnan (1996), Badhuri (2002), dan Majumdar (1999) menunjukkan bahwa pertumbuhan penjualan (sales growth) merupakan salah satu variabel yang berpengaruh terhadap struktur modal perusahaan. Hasil penelitian tersebut menunjukkan bahwa pertumbuhan penjualan berpengaruh positif terhadap struktur modal. Sehingga dapat disimpulkan bahwa semakin besar risiko bisnis suatu perusahaan maka semakin besar pula struktur modal perusahaan tersebut, begitu juga sebaliknya semakin rendah nilai risiko bisnis maka semakin kecil pula struktur modal perusahaan tersebut. Kemudian untuk variabel ukuran perusahaan dimana semakin besar ukuran perusahaan suatu perusahaan, maka semakin besar pula struktur modal perusahaan tersebut, begitu juga sebaliknya saat ukuran perusahaan mengalami penurunan maka struktur modal perusahaan 
tersebut juga ikut menurun. Pada variabel pertumbuhan penjualan dimana semakin besar pertumbuhan penjualan suatu perusahaan, maka semakin besar pula struktur modal perusahaan tersebut, begitu juga sebaliknya saat pertumbuhan penjualan mengalami penurunan maka struktur modal perusahaan tersebut juga ikut menurun. Berdasarkan pemaparan tersebut maka dapat dirumuskan hipotesis sebagai berikut. $\mathrm{H}_{1}$ : Risiko bisnis, ukuran perusahaan, dan pertumbuhan penjualan berpengaruh terhadap struktur modal.

Risiko bisnis perusahaan dapat digambarkan dengan mengukur fluktuasi dari laba perusahaan. Perusahaan yang mengalami fluktuasi laba menghadapi ketidakpastian kemampuan dalam hal mengumpulkan dana untuk melunasi pinjamannya kepada kreditur. Perusahaan yang memiliki banyak hutang akan mengakibatkan meningkatnya risiko kebangkrutan yang dihadapi karena semakin banyak pula kewajiban yang harus dipenuhinya. Berdasarkan hal tersebut, perusahaan yang memiliki risiko bisnis yang tinggi akan berusaha menjaga porsi hutangnya agar tidak membahayakan keberlangsungan perusahaan (Joni \& Lina, 2010). Temuan penelitian dari Wimelda dan Marlinah (2013), Joni dan Lina (2010), Theresia (2007), menemukan hasil bahwa risiko bisnis mempunyai pengaruh positif pada struktur modal. Hal ini berarti bahwa semakin meningkatnya risiko bisnis perusahaan akan cenderung menyebabkan peningkatan penggunaan hutang sebagai struktur modal perusahaan. Berdasarkan pemaparan tersebut maka dapat dirumuskan hipotesis sebagai berikut. $\mathrm{H}_{2}$ : Risiko bisnis berpengaruh terhadap struktur modal.

Ukuran perusahaan adalah nilai yang menggambarkan besar-kecilnya suatu perusahaan yang dapat dinyatakan dengan total aktiva atau total penjualan bersih. Untuk mendapatkan nilai ukuran perusahaan yang tinggi, perusahaan perlu menambah asetnya dengan cara mendapatkan pinjaman untuk membeli aset baru (Joni \& Lina, 2010). Berdasarkan hasil studi Thian (2012) perusahaan berpengaruh positif pada struktur modal. Hal ini berarti bahwa semakin meningkat nilai ukuran perusahaan maka perusahaan tersebut lebih cenderung menggunakan hutang sebagai struktur modalnya. Berdasarkan pemaparan tersebut maka dapat dirumuskan hipotesis sebagai berikut. $\mathrm{H}_{3}$ : Ukuran perusahaan berpengaruh terhadap struktur modal.

Brigham dan Houston (2001: 39) mengatakan bahwa perusahaan dengan penjualan yang relatif stabil dapat lebih aman memperoleh lebih banyak pinjaman dan menanggung beban tetap yang lebih tinggi dibandingkan dengan perusahaan yang penjualannya tidak stabil. Penelitian empiris yang telah dilakukan antara lain oleh Krishnan (1996), Badhuri (2002), dan Majumdar (1999) menunjukkan bahwa pertumbuhan penjualan (sales growth) merupakan salah satu variabel yang berpengaruh terhadap struktur modal perusahaan. Hasil penelitian tersebut menunjukkan bahwa pertumbuhan penjualan berpengaruh positif terhadap struktur modal. Semakin tinggi pertumbuhan penjualan perusahaan akan lebih aman dalam menggunakan hutang sehingga semakin tinggi struktur modalnya. Berdasarkan pemaparan tersebut maka dapat dirumuskan hipotesis sebagai berikut. $\mathrm{H}_{4}$ : Pertumbuhan penjualan berpengaruh terhadap struktur modal.

\section{Metode}

Desain penelitian yang digunakan adalah kuantitatif kausal. Pendekatan kuantitatif kausal merupakan penelitian pendekatan ilmiah terhadap pengambilan keputusan manajerial dan ekonomi yang bertujuan untuk mendapatkan bukti hubungan sebab akibat atau pengaruh dari variabel-variabel penelitian. Adapun variabel bebas dalam penelitian ini adalah risiko bisnis $\left(X_{1}\right)$, ukuran perusahaan $\left(X_{2}\right)$ dan pertumbuhan penjualan $\left(X_{3}\right)$, sedangkan variabel terikat dalam penelitian ini adalah struktur modal $(Y)$.

Subjek dalam penelitian ini adalah Perusahaan Subsektor Properti dan Real Estate yang terdaftar di Bursa Efek Indonesia. Sedangkan yang menjadi objek dalam penelitian ini adalah risiko bisnis, ukuran perusahaan, pertumbuhan penjualan dan struktur modal.Populasi dalam penelitian ini adalah perusahaan subsektor properti dan real estateyang terdaftar di bursa efek Indonesia yang berjumlah 53 perusahaan. Pengambilan sampel yang digunakan dalam penelitian menggunakan metode purposive sampling. Dari beberapa kriteria diperoleh 53 perusahaan, diantaranya terdapat 8 perusahaan yang tidak mempublikasikan laporan 
keuangan pada tahun 2017 - 2018, terdapat 20 perusahaan yang dimana laporan keuangan yang dilaporkan tidak lengkap dan jelas, dan terdapat 5 perusahaan yang tidak mempublikasikan laporan keuangan pada tahun 2016, sehingga jumlah sampel yang digunakan dalam penelitian ini adalah 20 perusahaan yang terdaftar di Bursa Efek Indonesia pada tahun 2017 - 2018. Metode analisis data yang digunakan dalam penelitian ini adalah analisis regresi linier berganda. Teknik ini digunakan untuk mengetahui pengaruh variabel bebas terhadap variabel terikat baik secara simultan maupun parsial. Analisis ini untuk mengetahui arah hubungan antara variabel bebas dengan variabel terikat apakah masingmasing variabel bebas berhubungan positif atau negatif dan untuk memprediksi nilai dari variabel terikat. Dalam penelitian ini yang menjadi variabel bebas yaitu risiko bisnis, ukuran perusahaan dan pertumbuhan penjualan, sedangkan yang menjadi variabel terikat yaitu struktur modal.

\section{Hasil dan Pembahasan \\ Hasil}

Penelitian ini menggunakan analisis regresi linier berganda dengan bantuan program aplikasi komputer Statistical Package for Social Science (SPSS) maka diperoleh hasil pengujian berupa Ringkasan Hasil Output SPSS seperti nampak pada Tabel 1.

Tabel 1.

Ringkasan hasil output SPSS analisis regresi linier berganda pengaruh risiko bisnis, ukuran perusahaan dan pertumbuhan penjualan terhadap struktur modal.

\begin{tabular}{|ccc|}
\hline Parameter & Nilai & $\boldsymbol{p}$-value \\
\hline $\mathrm{Ryx}_{1} \mathrm{x}_{2} \mathrm{x}_{3}$ & 0,535 & 0,006 \\
$\mathrm{R}^{2} \mathrm{yx}_{1} \mathrm{x}_{2} \mathrm{x}_{3}$ & 0,286 & 0,006 \\
$\varepsilon$ & 0,714 & - \\
$\mathrm{pyx}_{1}$ & 0,009 & 0,956 \\
$\mathrm{p}^{2} \mathrm{yx}_{1}$ & 0,000081 & - \\
$\mathrm{pyx}_{2}$ & $-0,507$ & 0,001 \\
$\mathrm{p}^{2} \mathrm{yx}_{2}$ & 0,257 & - \\
$\mathrm{pyx}_{3}$ & $-0,189$ & 0,256 \\
$\mathrm{p}^{2} \mathrm{yx}_{3}$ & 0,036 & - \\
$\mathrm{A}$ & 2,911 & 0,000 \\
$\beta_{1}$ & 0,100 & 0,956 \\
$\beta_{2}$ & $-0,093$ & 0,001 \\
$\beta_{3}$ & $-0,497$ & 0,256 \\
\hline
\end{tabular}

\section{Pembahasan}


Berdasarkan Tabel 1, maka dapat dijelaskan hubungan antar variabel yang terjadi sebagai berikut: (1) $\mathrm{Ryx}_{1} \mathrm{x}_{2} \mathrm{X}_{3}$ yang menyatakan terdapat pengaruh antara variabel risiko bisnis, ukuran perusahaan, dan pertumbuhan penjualan terhadap struktur modal sebesar0,535 (53,5\%) (2) $R^{2} \mathrm{yx}_{1} \mathrm{x}_{2} \mathrm{x}_{3}$ yang menyatakan besar sumbangan pengaruh antara variabel risiko bisnis, ukuran perusahaan, dan pertumbuhan penjualan terhadap struktur modal sebesar $0,286(28,6 \%)(3) \varepsilon$ yang menyatakan besar sumbangan pengaruh variabel lain terhadap struktur modalyaitu $0,714(71,4 \%)(4) p^{2} x_{1}$ menyatakan bahwa ada pengaruh dari risiko bisnis terhadap struktur modal yaitu sebesar $0,009(0,9 \%)(5) p^{2} y_{1}$ menyatakan bahwa besar sumbangan pengaruh dari risiko bisnis terhadap struktur modal yaitu 0,000081 (6) $\mathrm{pyx}_{2}$ menyatakan bahwa ada pengaruh dari ukuran perusahaan terhadap struktur modal yaitu sebesar $-0,507(50,7 \%)(7) \mathrm{p}^{2} \mathrm{yx}_{2}$ meyatakan bahwa besar sumbangan pengaruh dari ukuran perusahan terhadap struktur modal yaitu $0,257 \quad(25,7 \%)$ (8) py $x_{3}$ menyatakan bahwa ada pengaruh dari pertumbuhan penjualan terhadap struktur modal yaitu sebesar $-0,189$ (18,9\%) (9) $\mathrm{p}^{2} \mathrm{yx}_{3}$ menyatakan bahwa besar sumbangan pengaruh dari pertumbuhan penjualan terhadap struktur modal yaitu $0,036(3,6 \%)$

Pengaruh masing-masing variabel terhadap struktur modal pada tahun $2017-2018$ dapat dilihat seperti Gambar 1.

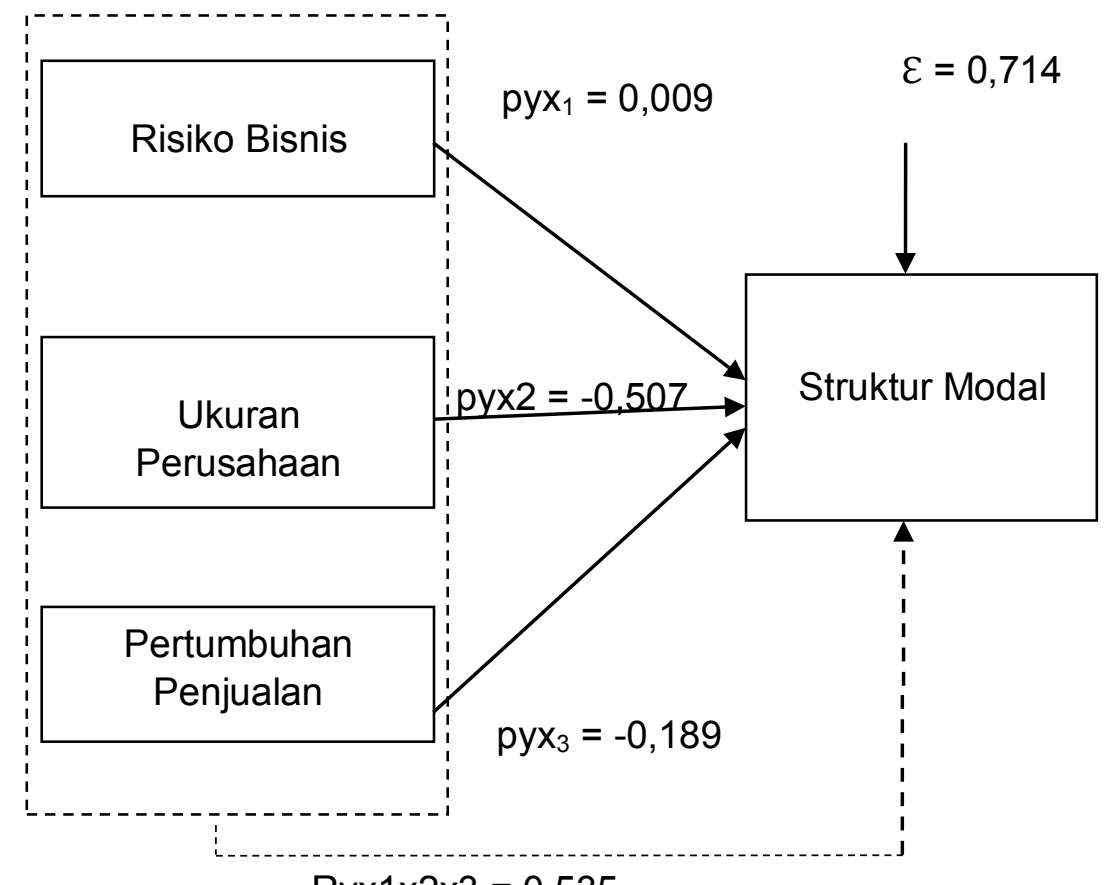

Ryx $1 \times 2 \times 3=0,535$

Gambar 1. Struktur pengaruh risiko bisnis, ukuran perusahaan, dan pertumbuhan penjualan terhadap struktur modal

Berdasarkan hasil uji regresiberganda padaTabel 1diperoleh nilai nilai konstanta $(\alpha)$ sebesar 2,911. Nilai koefisien regresi risiko bisnis $\left(\beta_{1}\right)$ sebesar 0,100 nilai koefisien regresi ukuran perusahaan $\left(\beta_{2}\right)$ sebesar $-0,093$ dan nilai koefisien regresi pertumbuhan penjualan $\left(\beta_{3}\right)$ sebesar $-0,497$. Sehingga persamaan regresi diformulasikan sebagai berikut.

$Y=2,911+0,100 X_{1}+\left(-0,093 X_{2}\right)+\left(-0,497 X_{3}\right)+\varepsilon$

Penjelasan hasil analisis regresi linier berganda sebagai berikut. (1) Konstanta sebesar 2,911 artinya bahwa apabila variabel risiko bisnis $\left(X_{1}\right)$, ukuran perusahaan $\left(X_{2}\right)$, dan pertumbuhan penjualan $\left(X_{3}\right)$ nilainya sama dengan nol, maka struktur modal $(Y)$ akan 
naik sebesar 2,911. (2) Nilai koefisien risiko bisnis $\left(\beta_{1}\right)$ sebesar 0,100 berpengaruh positif terhadap struktur modal $(Y)$. Ini berarti bahwa setiap risiko bisnis $\left(X_{1}\right)$ naik satu satuan maka variabel struktur modal $(Y)$ mengalami peningkatan sebesar 0,100 sehingga menjadi 3,011 dengan asumsi bahwa variabel lainnya tetap. (3) Nilai koefisien ukuran perusahaan $\left(\beta_{2}\right)$ sebesar $-0,093$ berpengaruh negatif terhadapstruktur modal $(Y)$. Ini berarti bahwa setiap ukuran perusahaan $\left(\mathrm{X}_{2}\right)$ naik satu satuan maka variabel struktur modal $(\mathrm{Y})$ mengalami penurunan sebesar 0,093 sehingga menjadi 2,818 dengan asumsi bahwa variabel lainnya tetap. (4) Nilai koefisien pertumbuhan penjualan $\left(\beta_{3}\right)$ sebesar $-0,497$ berpengaruh negatif terhadap struktur modal $(Y)$. Ini berarti bahwa setiap pertumbuhan penjualan $\left(\mathrm{X}_{3}\right)$ naik satu satuan maka variabel struktur modal $(\mathrm{Y})$ mengalami penurunan sebesar 0,497 sehingga menjadi 2,414 dengan asumsi bahwa variabel lainnya tetap.

Berdasarkan hasil uji regresi linear berganda diperoleh pada Tabel 1, menunjukkan hasil $\operatorname{Ryx}_{1} \mathrm{x}_{2} \mathrm{X}_{3}=0,535$ dengan $p$-value 0,006 <alpha 0,05 , yang menyatakan bahwa Ho ditolak yang berartirisiko bisnis $\left(X_{1}\right)$, ukuran perusahaan $\left(X_{2}\right)$, dan pertumbuhan penjualan $\left(\mathrm{X}_{3}\right)$ berpengaruh terhadap struktur modal $(\mathrm{Y})$. Berdasarkan hasil uji regresi linear berganda pada Tabel 1.diperoleh hasil yaitu besarnya hubungan pengaruh risiko bisnis terhadap struktur modal sebesar 0,009 dengan nilai $p$-value $0,956>$ alpha 0,05 , menyatakan bahwa Ho diterima yang berarti risiko bisnis $\left(X_{1}\right)$ berpengaruh positif namun tidak signifikan terhadap struktur modal $(\mathrm{Y})$.Berdasarkan hasil uji regresi linear berganda pada Tabel 1. diperoleh hasil yaitu besarnya hubungan ukuran perusahaan terhadap struktur modal sebesar $-0,507$ dengan nilai $p$-value $0,001<$ alpha 0,05 , menyatakan bahwa Ho ditolak yang berarti ukuran perusahaan $\left(X_{2}\right)$ berpengaruh negatif signifikan terhadap struktur modal $(\mathrm{Y})$.Berdasarkan hasil uji regresi linear berganda pada Tabel 1. diperoleh hasil yaitu besarnya hubungan pertumbuhan penjualan terhadap struktur modal sebesar $-0,189$ dengan nilai $p$-value $0,256>$ alpha 0,05 , menyatakan bahwa Ho diterima yang berarti pertumbuhan penjualan $\left(X_{3}\right)$ berpengaruh negatif namun tidak signifikan terhadap struktur modal $(\mathrm{Y})$.

Risiko bisnis, ukuran perusahaan, dan pertumbuhan penjualan secara bersamasama berpengaruh terhadap struktur modal pada perusahaan Sub Sektor Properti dan Real Estate di Bursa Efek Indonesia. Hasil penelitian tersebut menunjukkan semakin besar risiko bisnis suatu perusahaan maka semakin besar pula struktur modal perusahaan tersebut.Kemudian untuk variabel ukuran perusahaan dimana semakin besar ukuran perusahaan suatu perusahaan, maka semakin besar pula struktur modal perusahaan tersebut.Pada variabel pertumbuhan penjualan dimana semakin besar pertumbuhan penjualan suatu perusahaan, maka semakin besar pula struktur modal perusahaan tersebut.Hal ini didukung oleh penelitian Septiani dan Suaryana (2018) yang menyatakan bahwa risiko bisnis, ukuran perusahaan, dan pertumbuhan penjualan berpengaruh signifikan secara simultan terhadap struktur modal.

Risiko bisnis memiliki pengaruh positif namun tidak signifikan terhadap struktur modal pada perusahaan sub sektor properti dan real estate di bursa efek Indonesia. Hasil penelitian ini sejalan dengan teori Brigham dan Houston (2006), yang menyatakan bahwa perusahaan yang memiliki risiko bisnis tinggi, akan meningkatkan penggunaan utang sebagai sumber pendanaan. Hal ini juga mendukung hasil penelitian yang dilakukan oleh Indrajaya dkk., (2012), Kartika (2009), Riyazahmed (2012) yang menyatakan bahwa risiko bisnis memiliki pengaruh positif namun tidak signifikan terhadap struktur modal. Namun hasil ini penelitian berbeda dengan temuan Joni dan Lina (2010), Wimelda dan Marlinah (2013) dan Theresia (2007) yang menyatakan bahwa risiko bisnis tidak berpengaruh signifikan terhadap struktur modal. Apabila variabilitas pendapatan tinggi, maka risiko bisnis perusahaan akan tinggi sehingga laba yang dihasilkan cenderung berfluktuasi yang 
berarti pendapatan tidak stabil, dengan adanya risiko bisnis yang tinggi perusahaan cenderung tidak mengurangi utang, tetapi tetap menggunakan utang dalam memenuhi kebutuhan dananya.Risiko bisnis tidak memiliki implikasi terhadap struktur modal dalam penelitian ini, Hal ini berarti risiko bisnis kurang diperhatikan oleh pihak perusahaan dalam menentukan besar kecilnya hutang. Hal ini terjadi perbedaan pendapat antara pihak perusahaan dan pihak investor karena investor cendurung menyukai risiko bisnis yang tinggi dengan harapan mendapatkan pengemabalian dan return yang lebih tinggi pula.

Ukuran perusahaan terhadap struktur modal memiliki pengaruh negatif dan signifikan pada perusahaan sub sektor properti dan real estate di bursa efek Indonesia. Hal ini sesuai dengan teori pecking order yaitu semakin besar ukuran perusahaan mempengaruhi kebijkan manajemen untuk lebih sedikit menggunakan hutang.Hasil ini didukung oleh penelitian yang dilakukan oleh Damayanti (2017) yang menyatakan bahwa ukuran perusahaan berpengaruh negatif signifikan terhadap struktur modal. Hal ini dikarenakan ukuran perusahaan dinilai dari total aset yang dimiliki oleh perusahaan untuk kegiatan operasionalnya, semakin besar ukuran perusahaan akan semakin besar pula modal yang dibutuhkan untuk kegiatan operasionalnya. Salah satu sumber modal yang bisa didapatkan oleh perusahaan yaitu dengan hutang pada pihak eksternal perusahaan, sehingga dapat disimpulkan bahwa semakin besar ukuran perusahaan semakin besar pula hutangnya.Aset yang dijadikan jaminan untuk memperoleh hutang, dapat menimbulkan kekhawatiran bagi para investor karena tingginya risiko didalam perusahaan tersebut yang dapat memperbesar potensi terjadinya kebangkrutan.Ukuran perusahaan memiliki implikasi terhadap struktur modal, dimana ukuran perusahaan adalah nilai yang menggambarkan besar-kecilnya suatu perusahaan. Perusahaan yang besar maka akan lebih mudah untuk memperoleh hutang. Namun didalam perusahaan ini semakin besar ukuran perusahaan maka akan mempengaruhi kebijkan manajemen untuk lebih sedikit menggunakan hutangnya untuk menghindari risiko-risiko yang mungkin terjadi.

Pertumbuhan penjualan berpengaruh negatif terhadap struktur modal pada perusahaan sub sektor properti dan real estate di bursa efek Indonesia. Artinya, bahwa perusahaan dengan pertumbuhan penjualan tidak mempengaruhi struktur modal.Dimana perusahaan dengan pertumbuhan penjualan yang tinggi ataupun rendah dalam memenuhi kebutuhan dananya tidak selalu mengambil dananya dari hutang, melainkan lebih memilih untuk menggunakan pendanaan internal.Hasil ini didukung oleh penelitian yang dilakukan oleh Safitri dan Siti (2017) menunjukkan bahwa pertumbuhan penjualan (sales growth) berpengaruh tidak signifikan terhadap struktur modal.Pertumbuhan penjualan tidak memiliki implikasi terhadap struktur modal, dimana perusahaan dengan pertumbuhan penjualan yang tinggi ataupun rendah dalam memenuhi kebutuhan dananya tidak selalu memperoleh dananya dari hutang, melainkan lebih memilih untuk menggunakan pendanaan yang berasal dari perusahaan itu sendiri (pendanaan internal).

\section{Simpulan dan Saran \\ Simpulan}

Berdasarkan hasil pengujian statistik dan hipotesis serta pembahasan yang telah dilakukan pada bab sebelumnya, maka dapat ditarik beberapa kesimpulan sebagai berikut: (1) Risiko bisnis, ukuran perusahaan dan pertumbuhan penjualanberpengaruh signifikan terhadap struktur modal pada perusahaan properti dan real estateyang terdaftar di bursa efek Indonesia. (2) Risiko bisnis berpengaruh positif namun tidak signifikan terhadap struktur modal pada perusahaan properti dan real estate yang terdaftar di bursa efek Indonesia. (3) Ukuran perusahaan berpengaruh negatif dan signifikan terhadapstruktur modal pada perusahaanproperti danreal estate yang terdaftar di bursa efek Indonesia. (4) Pertumbuhan 
penjualanberpengaruh negatif namun tidak signifikan terhadap struktur modal pada perusahaan properti dan real estateyang terdaftar di bursa efek Indonesia.

\section{Saran}

Berdasarkan hasil pembahasan dan simpulan yang telah dikemukakan di atas, maka dapat diajukan beberapa saran sebagai berikut. (1) Bagi perusahaan yang diteliti diharapkan agar dapat mengoptimalkankomposisi hutang dan modal usaha agar dapat menguntungkan perusahaan dari segi keuangan, sehingga calon investor akan memutuskan untuk berinvestasi pada perusahaan. (2) Bagi penelitian berikutnya diharapkan menambah rasio keuangan lainnya sebagai variabel bebas, karena sangat dimungkinkan rasio keuangan lain yang tidak dimasukkan dalam penelitian ini berpengaruh terhadap Struktur Modal. Peneliti diharapkan menerapkan penelitian ini pada subyek penelitian yang berbeda dan memperpanjang periode penelitian sehingga dapat menguji kehandalan dari penelitian ini.

\section{Daftar Pustaka}

Al-Shubiri, Faris. 2010. Determinant of Capital Structure Choice: A Case Study of Jordanian Industrial Companies. An-Najah Univ. J. of Res. (Humanities), Vol 24(8): Hal. 24582494.

Andre I Putu. 2014. Pengaruh Profitabilitas, Struktur Aset, dan Pertumbuhan Penjualan Terhadap Struktur Modal Serta Harga Saham. Jurnal Akuntansi Universitas Udayana, Vol 6: Hal. 515-529 Awan, Tariq Naeem, Majed Rashid, dan Muhammad Zia-ur-Rehman. 2011. Analysis of The Determinant of Capital Structure in Sugar and Aliied Industry. International Journal of Business and Social Sciences, Vol 2(1): Hal. 221-229.

Bhaduri, S.N. 2002. Determinants Of Corporate Borrowing: Some Evidence from the Indian Corporate Structure. Journal Of Economic and Finance, Vol. 26 No. 2, hlm. 200-215.

Brigham, E.F. dan J.F. Houston. 2006. Fundamentals of Financial Management. Tenth Edition.Cengange Learning Asia. Singapore. Terjemahan A.A. Yulianto. Dasar-dasar Manajemen Keuangan. Edisi Kesepuluh. Jilid dua. Jakarta: Salemba Empat.

Brigham, Eugene F. dan Joel F. Houston, (2001).Manajemen Keuangan, Edisi 8, Jakarta: Erlangga

Brigham, Eugene F. dan Joel F. Houston. 2011. Dasar-dasar Manajemen Keuangan. Edisi 11. Jakarta: Salemba Empat.

Brigham, E.F., and Houston, J.F. 2013.Dasar-Dasar Manajemen Keuangan (Essentials of Financial Management). Edisi 11, Buku 2. Jakarta: SalembaEmpat.

Firnanti, Friska. 2011. Faktor-faktor yang mempengaruhi Struktur Modal Perusahaan Manufaktur di Bursa Efek Indonesia. Stei Trisakti .Jurnal Bisnis dan Akuntansi 13 (2): 119-128.

Halim, Abdul dan Theresia.2007. Manajemen Keuangan Daerah Pengelolaan Keuangan Daerah Edisi kedua.Yogyakarta : UPP STIM YKPN.

Heriyani. 2011. Faktor-Faktor Yang Mempengaruhi Struktur Modal Pada Perusahaan Industri Barang Konsumsi Yang Terdaftar Di Bursa Efek Indonesia Periode 2008-2010. Jurnal Administrasi Bisnis, Vol 12(3): Hal. 1-13.

Indrajaya. et al., 2011. Pengaruh Struktur Aktiva, Ukuran Perusahaan,Tingkat Pertumbuhan, Profitabilitas, dan Resiko Bisnis terhadap Struktur Modal: Studi Empiris pada 
Perusahaan Sektor Pertambangan yang Listing di Bursa Efek Indonesia. Jurnal Akurat Jurnal Ilmiah Akuntansi 06.

Joni dan Lina. 2010. Faktor-Faktor yang Mempengaruhi Struktur Modal. Jurnal Bisnis dan Akuntansi, Vol. 12. No. 2, Agustus, P. 81-96

Krishnan, J dan Krishnan. 1996. The Role of Economic Trade-Offs in the Audit Opinion Decision : An Empirical Analysis. Vol. 11, p. 565-586.

Liem, Jemmi Halim. 2013. Faktor-Faktor Yang Mempengaruhi Struktur Modal Pada Industri Consumer Good Yang Terdaftar di BEI Periode 2007-2011. Jurnal IImiah Mahasiswa Universitas Surabaya, Vol 2(1): Hal. 1-11.

Majumdar, S. K. (1999). Foreign ownership and profitability: property rights, control and the performance of firms in Indian Industry. 46(3), 209-238. ISSN: 00222186.

Sayılgan, Güven., Hakan Karabacak, dan Güray Küçükkocao. 2006. The Firm- Specific Determinants Of Corporate Capital Structure: Evidence From Turkish Panel Data. Investment Management and Financial Innovations, Vol 3(3): Hal. 125-139.

Wimelda dan Marlinah, 2013. "Variabel-Variabel yang Mempengaruhi Struktur Modal pada Perusahaan Publik Sektor Non-Keuangan”,Media Bisnis, Vol 5,No.3, hlm 200-213.

Winahyuningsih, Panca., Kertati Sumekar, dan Hanar Prasetyo. 2011. Analisis Faktor-Faktor yang Mempengaruhi Struktur Modal pada Perusahaan Manufaktur yang Go Public di Bursa Efek Indonesia. Jurnal Ekonomi, Hal. 1-17. 